\title{
From recognising health rights to realising labour protections? Sex work, ILOAIDS and the Decent Work Agenda in Ghana
}

\section{Ellie Gore ${ }^{1}$ (D)}

Received: 1 February 2021 / Accepted: 21 April 2021 / Published online: 21 June 2021

(c) The Author(s), under exclusive licence to Institute for Global Public Policy, Fudan University 2021

\begin{abstract}
This paper examines recent evolutions in global development policy that link decent work, HIV and sex work-particularly through the ILO Programme on HIV/AIDS and the World of Work-and considers the implications for migrant sex workers in Ghana. Drawing on original primary data gathered in 2020, namely interviews with grassroots NGOs based in Accra, the paper explores the conditions for and barriers to expanding rights-based sexual health frameworks to include the promotion and protection of sex workers' labour rights. The paper finds that civil society actors face multiple barriers to expanding sexual health frameworks, which include Ghana's prevailing socio-legal regime of prohibition and stigmatisation, the overwhelming focus of development funding on HIV, and the failure of existing policy efforts to address the political-economic determinants of migrant women's experiences of labour exploitation in the sex sector. Theoretically, the paper contributes to the interdisciplinary literatures on commercial sex, gender, migration, and development policy by advancing a feminist political economy analysis of the constraints and opportunities for civil society actors seeking to advance sex workers' rights within and beyond sexual health.
\end{abstract}

Keywords Migration · Decent work $\cdot$ Sex work $\cdot$ Labour rights $\cdot$ Ghana $\cdot$ Feminist political economy

Paper prepared for Global Public Policy and Governance Special Issue edited by Nicola Piper and Elspeth Guild, January 2021.

Ellie Gore

e.gore@sheffield.ac.uk

1 SPERI, The University of Sheffield, Sheffield, UK 


\section{Introduction}

The ILO's "Decent Work Agenda" has become the cornerstone of international development efforts to improve labour standards in the global economy. Since the 2000s, the parameters of the Decent Work Agenda have been significantly expanded, as part of an attempt to better incorporate vulnerable and marginalised workers-namely informal, migrant, and women workers-to recognise (paid) domestic work, and to address extreme forms of exploitation and abuse, typically referred to as forced labour and human trafficking (ILO, 2011, 2016). This process of expansion has been contested (Standing, 2008; Vosko, 2002) and multiple and at times conflicting conceptualisations of 'decent work' operate across different policy fields (Di Ruggiero et al., 2015). ${ }^{1}$ Nonetheless, the ILO's broadened understanding of decent (and 'unacceptable forms of') work (Fudge \& McCann, 2015) has gained widespread policy traction. This is notably reflected in the inclusion of decent work, and its interconnections with gender equality and safe migration, in the Sustainable Development Goals (SDGs).

Sex work, however, has occupied a complex and at times ambiguous position visà-vis the Decent Work Agenda and, more recently, the SDGs. The ILO has not, for example, publicly advocated the decriminalisation of sex work (unlike a number of other UN agencies, such as UNFPA and UNAIDS) and responsibility for regulatory frameworks has been left largely at the national level (García, 2018; Kempadoo \& Ghuma, 1999). This element of ambiguity is reproduced in the SDGs, which, as Elias and Holliday (2019) note, provide multiple - and not necessarily compatible-potential lenses through which to interpret sex work, including decent work, human trafficking, and gender-based violence (GBV). Such inconsistencies and slippages reflect a longstanding tendency within some global policy discourse to conflate sex work with slavery and trafficking (Kempadoo, 2015; Mgbako, 2016). In a development context, this conflation has been reinforced by racialised stereotypes of sex workers as passive and voiceless victims in need of "rescue" (Agustín, 2006; Doezema, 2001; Kempadoo, 2015). As such, the ILO's reticence on the issue of decriminalisation reflects the highly contested terrain that surrounds the governance and regulation of sex work, as well as a wider lack of political consensus on appropriate interventions, which cuts across government, civil society, activist, and academic spheres.

This paper examines the implications of shifting (and competing) policy paradigms for the protection and promotion of sex workers' rights in Ghana. Policy and legal measures aimed at improving the lives and protecting the rights of sex workers remain the subject of intense debate in the international domain, especially as this pertains to 'criminal justice' vs 'labour rights' approaches (sometimes used

\footnotetext{
1 In particular, Di Ruggiero et al (2015) highlight how 'decent work' is conceptualised differently across economic, social, and health policy discourses and as articulated through the work of the World Bank, the ILO, and the World Health Organization.
} 
interchangeably with 'abolitionist' vs 'advocate' positions) (Kotiswaran, 2014). ${ }^{2}$ However, there have been a number of evolutions in the ILO's position that, at the very least, indicate a growing recognition that 'sex work is work' (ILO, 1999, 2014; see also NSWP, 2017). Of particular significance over the past decade is the bringing together of the Decent Work Agenda with efforts to address HIV/AIDS in the workplace, which have been explicitly oriented to include sex work. To this end, the ILO Programme on HIV/AIDS (ILOAIDS) was formally established in 2000 in order to support "the rights of people living with HIV with a focus on labour rights" and, with regard to sex work, to promote "the inclusion of female and male sex workers and their clients in HIV responses at the international, national, sectoral and workplace levels" (ILO, 2012:1). In the Ghanaian context, the ILO has been an important actor shaping national policy on HIV/AIDS and the workplace and, with its wider strategic focus on 'Key Populations' (KPs) such as Female Sex Workers (FSWs) and Men who have Sex with Men (MSM), the country is considered to have one of the most comprehensive HIV policies on the African continent (Gyamerah, 2017; Makofane et al, 2013).

Against this background, this paper traces some of the key evolutions in Ghanaian policy on HIV, the world of work, and sex work, illuminates the terrain of NGO and CBO organising around sex workers' health and labour rights, and examines the opportunities and limitations of a sexual health/decent work approach in this context. Specifically, the paper explores the conditions for and barriers to expanding rights-based sexual health frameworks to include the protection and promotion of sex workers' labour rights. While there is now a heterogenous body of literature documenting the impact of anti-trafficking legal and policy approaches (Agustín., 2007; Anderson \& Andrijasevic, 2008; Doezema, 2005; Kempadoo, 1998; O'Connell Davidson, 2013, 2015), the convergence of HIV prevention with labour rights approaches to sex work - as articulated through the work of ILOAIDSremains underexplored. There is a notable paucity of data on these dynamics in West Africa, including Ghana, and West African sex workers have seldom featured as key protagonists in the academic and activist debates surrounding sex work and sex trafficking. Yet across sub-Saharan Africa, sexual health represents a key paradigm through which civil society (and some governmental) support for sex workers is operationalised. In other words, in contexts like Ghana, HIV/public health approaches to sex work continue to predominate-rather than anti-trafficking and/ or GBV approaches - in terms of development policy interventions aimed at reaching out to and 'empowering' sex workers at the grassroots level. In light of this, I focus my analysis primarily on the development and implementation of HIV policy as it pertains to sex work in Ghana and more microlevel rights-based interventions to support sex workers carried out by a handful of NGOs based in the capital

\footnotetext{
${ }^{2}$ For the purposes of this analysis, I use these labels- 'advocate/labour rights' (henceforth labour rights) vs 'abolitionist/- criminal justice' (henceforth criminal justice) approaches - to locate different positions within the (feminist) sex work debates and to highlight how these (dis)connect to/from dominant development policy paradigms regarding sex work. While this terminology is adequate for this analysis, it is notable that these positions in fact comprise a variety of perspectives, approaches, actors, and aims, which are not all internally consistent (for a fuller discussion of these nuances, see Kempadoo, 2015).
} 
city of Accra. Empirically, the paper draws on findings from a larger multi-sector study of labour unfreedom among migrant women workers in Ghana, namely five expert interviews with community- and NGO-based organisers and activists working on sex work and human rights in Accra conducted in 2020 (in addition, the study comprises sixty semi-structured interviews with migrant women working in the sex and domestic sectors, with this component of data collection ongoing at the time of writing). ${ }^{3}$ From an analytical perspective, the civil society focus of this paper is informed by Sara Kallock's (2018) study of frontline practitioners and agencies in England, who, she notes, have received limited attention in the cross-disciplinary literature on sex work. This is despite playing a "pivotal role in how policy is carried out in the lives of sex working service users" (Kallock, 2018: 394). Thus, while my sample is relatively small, the data is deemed sufficient for an exploratory, qualitative analysis of policy and practical dynamics, given both the limited number of civil society actors supporting sex workers on the ground and the broader lack of research on frontline sex work interventions from a decent work perspective (as opposed to an epidemiological one) in this context.

The paper argues that re-positioning sex work as simultaneously an issue of labour rights and public health may represent a pragmatic move on the part of international organisations, such as the ILO. In Ghana, however, the development of holistic sexual health/labour rights approaches has been constrained and undermined by the prevailing socio-legal landscape of prohibition, which criminalises any person who "lives on the earnings of prostitution" (Criminal Code, 1960), and stigmatisation. In practice, this means that grassroots organisations' attempts to move beyond sexual health to address a wider range of issues, including sex workers' labour and living conditions, and to 'empower' sex workers to claim their rights have been severely hampered, not least by sex workers' ongoing experiences of violence, intimidation and harassment at the hands of the Ghanaian police. Put simply, the vast majority of rights and protections-health, labour or otherwise-remain inaccessible to sex workers in the country. This lack of rights and protections is especially pronounced for intra-regional migrant sex workers, typically originating from Nigeria, Côte d'Ivoire, Togo and Liberia and other internal migrants, typically originating from the Northern, Central, Volta and Ashanti regions of the country, who make up a significant proportion of sex workers operating in metropolitan areas of the country.

The paper comprises four parts. In part one, I examine the extant literature on sex work, gendered migration processes, and development policy, drawing in particular on recent political economy accounts of sex work and the impact of the anti-trafficking paradigm, as well as postcolonial and Global South perspectives on sex workers' organising and HIV prevention initiatives. I aim to fuse together and move forward these insights by applying a feminist political economy analysis to sexual health/ labour rights approaches to sex work in Ghana. Part two looks at the evolving policy position of the ILO vis-à-vis sex work and decent work, the work of ILOAIDS

\footnotetext{
3 This study is funded through a Global Challenges Research Fellowship, awarded to the PI (author) as part of the Research England QR GCRF Institutional Allocation at the University of Sheffield.
} 
and Recommendation 200, and its impact on HIV policy in Ghana. Part three examines the current interventions to advance sex workers' rights, as carried out by a small number of NGOs and CBOs, and examines how competing legal and policy approaches play out at the grassroots level, particularly in relation to the political economic realities of migrant sex workers' lives. Part four concludes.

\section{Understanding development, migration and sex work using (feminist) political economy}

The two programme areas where the ILO's work directly impacts on sex workforced labour and HIV-parallel, to a degree, the two dominant policy paradigms on sex work in the international domain: firstly, the anti-trafficking and modern slavery approach, which has become increasingly embedded across (Northern) government, INGO and other civil society spheres over the past two decades; and secondly, a more rights-based approach focused on HIV prevention (Kotiswaran, 2011). In terms of the first paradigm, a now substantial corpus of scholarship—cutting across feminist and postcolonial political economy, development studies and labour geography-has uncovered the failures and limitations of anti-trafficking approaches, across a range of geographic contexts, including East and South East Asia (Heumann et al., 2016; Kempadoo et al., 2016), South America (Blanchette et al, 2013), the Caribbean (Kempadoo, 1998) and Europe (Agustín, 2007; Andrijasevic, 2010). Critiques center on, inter alia, the role of anti-trafficking approaches in undergirding and legitimating restrictive and punitive immigration regimes (which disproportionately impact on migrant sex workers), bolstering conservative and traditionalist ideologies relating to gender, sexuality and 'prostitution' and failing to concretely support women and children who experience the most extreme forms of exploitation (Agustín, 2006, 2007; Bernstein, 2010; Doezema, 2005; O’Connell Davidson, 2006, 2013, 2015; Hashim \& Thorsen, 2011; Kinney, 2014).

These accounts form part of a wider interdisciplinary literature that usefully documents the growth and character of the global sex trade in the context of globalisation (Bhattacharya, 2005; Bernstein, 2010; Penttinen, 2008), particularly as this is constituted through increasing cross-border flows of migration (Ehrenreich \& Hochschild, 2003)_including trafficking and other informal forms of labour migration (O'Connell Davidson, 2006; Piper \& Uhlin, 2002) — and the growth of international sex tourism (Bernstein \& Shih, 2014; Kempadoo, 1999; Padilla, 2007; Pettman, 1997). Feminist political economists have further highlighted the interrelationship between (women's) informal, highly precarious and unprotected work in the global sex trade and the structures and functioning of the formal economy (Enloe, 1990; Peterson, 2003; Federici, 2006; see also Smith, 2012 on male sex work). This questioning of dichotomies is similarly applied to the forced-voluntary binary in sex work and migration (O'Connell Davidson, 2013), with scholars (Agustín, 2007; Andrijasevic, 2010) instead highlighting the agency of migrant sex workers in conditions of material hardship, insecurity and household precarity arising from economic restructuring. From a political economy perspective, this emphasis on structures rather than individuals (and on agency within structure, in a sense) is important and 
connects to a broader critique of what Julia O'Connell Davidson (2013: 177) calls "liberal dyads": forced/voluntary, illegal/legal, slavery/freedom. These dyads work to obscure more than they reveal about the embeddedness of unfreedom within the contemporary capitalist economy (Cruz, 2018; O'Connell Davidson, 2013) and specifically the interconnections between debt and unfreedom in both legally sanctioned and irregular forms of labour migration (see also Strauss, 2012). Thus, the political economy (and political economy-adjacent) literature illuminates how migrant workers navigate the gendered and racialised hierarchies that constitute the global sex industry, as these are embedded within and reproduced through local and transnational labour markets, migration circuits and unequal North-South power relations, and in situations marked by varying degrees of unfreedom and exploitation.

An emphasis on systematic and interconnected relations of unfreedom in the global economy should not be read as a rejection of trafficking as a concept tout court, since it is evident that people, frequently women and children, are moved into sexual exploitation within and across borders using forceful, coercive, deceptive or otherwise abusive means, including into, out of, and within West Africa (IOM, 2020). ${ }^{4}$ Yet, it is also the case that slavery and trafficking as a paradigm has come to dominate the international policy space around informal migration and sex work in a way that has led to misunderstanding and mischaracterisation of their root causes and effects, particularly where this has dovetailed with international government interest in increased security and tightening border and immigration regimes (O'Connell Davidson, 2013, 2015). In the Ghanaian context, Samuel Okyere (2017: 103) highlights the partial and problematic evidence base that informs NGO-led anti-child trafficking discourse and how this limits policymakers' ability to understand "the underlying causes of Ghanaian children's labour mobility", which reflect both historical and contemporary dynamics of inequality, including legacies of colonial underdevelopment in Northern Ghana. In terms of patterns of adult labour mobility in the sex sector specifically, there is a similar scarcity of data on the actual existing labour conditions encountered by migrant women workers and how these link to the political economy of (feminised) migration, patterns of uneven development and the social relations of production and reproduction.

In the literature on migration and poverty in Ghana, scholars (Adepoju, 2005; Litchfield \& Waddington, 2003) document how global economic restructuring and the growth of the informal sector have led to a 'feminisation' of migration (both at the national level and across West Africa) over the past two decades. Thus, while rural-urban, north-south migration in Ghana is not a new phenomenon, it is characterised by an increasingly diverse set of movements and flows (Adepoju, 2005; Anarfi et al., 2003) with more cyclical, seasonal and otherwise temporary forms of internal migration. This includes the intensification of short-distance independent female migration; whereby, significant numbers of young women and girls migrate from rural areas to metropolitan areas in the south of the country in search of work.

\footnotetext{
4 Although the ILO (2001) have previously noted that instances of child trafficking for sexual exploitation in West Africa were vastly outnumbered by cases of children trafficked into other forms of work, notably domestic work.
} 
Many of these migrants end up in precarious and exploitative forms of work in the informal sector, including working as kayayei (or head-porters) and in sex and domestic work (Awumbila \& Ardayfio-Schandorf, 2008; Awumbila et al., 2017; Onyango et al., 2015). Although a full discussion of these dynamics is beyond the scope of this paper, this provides key context for my analysis of policy and practical interventions aimed at advancing sex workers' health and labour rights, particularly in terms of understanding the political economic realities and patterns of exploitation facing migrant sex workers and the extent to which these are reflected and addressed in existing policy efforts. ${ }^{5}$

In terms of the second paradigm, the proliferation of HIV-related funding has been widely noted in the feminist activist and academic literature on sex work in the Global South, with diverging views on its value and implications (Jeffreys, 2009; Kempadoo, 1998; Kotiswaran, 2011; Magar, 2012). Although scholars on both sides of the sex work debates critique public health approaches (see Jeffreys, 2009; Kotiswaran, 2011), Kempadoo (1998) highlights how HIV prevention initiatives in the Dominican Republic have engendered change beyond their original aims, primarily by shaping and advancing the development of sex worker-led organisations and movements (see also Showden and Majic, 2014). Elsewhere, Kotiswaran (2011) critically traces the complex of public and private actors mobilised under the banner of HIV prevention in India. She argues that although these actors typically advance "right-based approaches", these are largely disconnected from the legal frameworks and material circumstances that mediate sex workers' lived experience. The dominant public health approach is therefore a contradictory one; it promotes a selective set of rights, "without unequivocally advocating decriminalisation" (Kotiswaran, 2011: 8). As this suggests, a 'rights-based' public health framing is not necessarily synonymous with a labour rights perspective on sex work. In Ghana, however, some NGOs working on HIV prevention among sex workers have increasingly moved towards a more critical, labour rights position, including advocating decriminalisation (while sex worker-led organisations are yet to be formally established). By contextualising these shifts in relation to an emerging sexual health/decent work policy nexus at ILOAIDS, which cautiously aims to include sex work, the paper examines the limitations and opportunities this presents for grassroots NGOs and CBOs in Ghana. In so doing, the paper addresses an empirical gap in the existing literature, which has shed valuable light into the impact of HIV initiatives on civil society and sex worker-led organising across a range of geographic settings, but has, to date, paid little attention to West Africa. ${ }^{6}$

At a more macrolevel, recent feminist political economy analyses of the SDGs and decent work agenda from a gendered perspective (Rai et al., 2019) and specifically the "promises and pitfalls" of the SDGs for advancing sex workers' rights (Elias and Holliday, 2019) further illuminate the contradictions and tensions that inhere in the current global development policy on decent work, as well as the need

\footnotetext{
5 This also provides a key research question animating the wider study from which this data is drawn.

${ }^{6}$ For an exception see Tandia (1998) on HIV prevention and empowerment initiatives for male sex workers in Senegal.
} 
to prioritise a "gender and labour rights approach" (Rai et al., 2019: 368) in relation to (paid and unpaid) domestic and sex work. When it comes to policy-focused studies on sex work in Africa, however, the literature is broadly bifurcated; on the one hand, studies examine anti-trafficking and slavery approaches, with a particular focus on child trafficking (on Ghana see Okyere, 2017; Manzo, 2005); on the other, a vast public health literature looks at HIV policies and other sexual and reproductive health issues among sex workers (on Ghana, see Onyango et al, 2015; Laar \& DeBruin, 2017). This paper seeks to both build on the feminist political economy literature on decent work and the SDGs and move beyond a focus on either public health or anti-trafficking in Africa by examining how NGO interventions focused on "Female Sex Workers" (dis)connect to/from broader development policy efforts around HIV and decent work.

In terms of methodology, the data used in this paper is drawn from a larger, multi-sector qualitative study of labour unfreedom among migrant women in Ghana, which entails 60 semi-structured interviews with workers in the sex and domestic sectors ( $n=30$ per sector), conducted in 2021. This paper draws on data gathered during stage one of the study; namely, ten expert interviews with NGO and CBO staff engaged in human rights programming aimed at sex and domestic workers in the cities of Accra and Kumasi ( $n=5$ per sector). Interviewees were identified following a desk-based literature review and mapping exercise of key actors working on sex and domestic work in Ghanaian civil society. The results of the mapping exercise were further refined by the project's academic partners at the University of Ghana. Owing to the coronavirus pandemic, interviews were conducted via telephone by the PI between May and September 2020, using a semi-structured format. Interview questions covered a range of topics that shed light into this paper's research question, including the history, funding and structure of the organisation, current and previous programmatic work, key human rights issues and challenges and priorities for the future. Interview transcripts were coded and analysed using Nvivo 12 software.

\section{Sex work, the ILO and HIV policy in Ghana}

Before looking in detail at microlevel NGO and CBO practices in Ghana, I wish to elaborate briefly on the policy context regarding decent work, sex work and international development described in the Introduction. The Decent Work Agenda has provided the primary organising framework for ILO policy and programming since the late 1990s and is itself underpinned by the 1998 ILO Declaration on Fundamental Principles and Rights at Work (also referred to as the 'Social Declaration'). The Social Declaration (ILO, 1998) commits member states to protecting and promoting principles and rights across four key categories: freedom of association and the effective recognition of the right to collective bargaining; the elimination of forced or compulsory labour; the abolition of the worst forms of child labour; and the elimination of discrimination in respect of employment and occupation. Leah Vosko (2002; see also Standing, 2008) notes that the development of this more integrative, multifaceted understanding of labour at the ILO has been contested, with 
the Decent Work Agenda effectively representing a compromise between competing forces, specifically corporate interests supported by predominantly Northern states on the one hand, and other member states, trade unions (especially those representing informal workers), women's organisations and NGOs advocating the interests of historically marginalised workers on the other (Vosko, 2002: 39). Vosko's emphasis on the complex and conflicting forces shaping policy is similarly insightful for understanding the ILO's position on sex work (albeit with a partially different set of interests and drivers). In the same year as the Social Declaration, for example, ILO Senior Specialist Lin Leam Lim published a book on the sex sector in SouthEast Asia that highlighted its significant economic scale and contribution and called for a review of existing policy and legal frameworks, including the recognition of sex work as a "legal occupation with protection under labour law" (1998: 2). Lim's conclusions elicited a mixed reception from policy, activist and civil society actors at the time and, against a backdrop of ongoing politicisation, the ILO has since trodden a cautious public line on the issue of legal reform that emphasises national-level responsibility and autonomy (García, 2018: 108).

Although labour rights scholars and activists (Bindman \& Doezema, 1997; Kempadoo \& Ghuma, 1999) have criticised the ILO's ambiguous approach to sex work-especially the absence of an ILO Convention-the launch of the first ILO international labour standard on HIV/AIDS and the world of work in 2010 was welcomed by some prominent international sex worker organisations as marking an important-if circumscribed — step forward in the struggle to link the Decent Work Agenda to working conditions and rights in the sex sector (NSWP, 2017; see also Empower, 2016). This standard, Recommendation 200 (ILO, 2010a), builds on the ILO Code of Practice on HIV and AIDS to include a range of principles and standards regarding: discrimination or stigmatisation of workers on grounds of real or perceived HIV status; access to HIV prevention, access to treatment, care and support; worker participation in HIV programmes; the occupational transmission of HIV; and privacy and confidentiality regarding HIV status. It further states that "measures to address HIV and AIDS in the world of work should be part of national development policies and programmes, including those related to labour, education, social protection and health" (ILO, 2010a: 4).

Recommendation 200 does not explicitly identify sex workers as a group and proposed amendments to include them as a discrete category of workers were ultimately rejected. ${ }^{7}$ Nonetheless, subsequent documents published by the ILO have sought to underscore the inclusive nature of the Recommendation vis-à-vis sex work. This includes: Reaching out to Sex Workers and their Clients (ILO, 2012), which proposes that HIV prevention interventions with sex workers also address structural drivers - such as lack of social protections, stigma, discrimination, marginalisation

\footnotetext{
${ }^{7}$ Specifically, the Recommendation (ILO, 2010a: 6-7) covers “(a) all workers working under all forms or arrangements, and at all workplaces [...] (b) all sectors of economic activity, including the private and public sectors and the formal and informal economies; and (c) armed forces and uniformed services." As such, the Netherlands, representing Spain and Sweden, proposed to introduce a further category "(d) sex workers".
} 
and violence-that make sex workers vulnerable to HIV; and Leaving No One Behind: Reaching Key Populations through workplace action on HIV and AIDS (ILO, 2014), which notes that "Sex workers, men who have sex with men, transgender people and people who inject drugs face many barriers, including criminalization" (ILO, 2014: 1). While recognising criminalisation as a "barrier" is evidently not the same as advocating decriminalisation, the establishment of ILOAIDS and Recommendation 200 has been identified as a significant policy shift, insofar as it repositions HIV prevention as the "entry point into the debate on commercial sex" (García, 2018: 108) and enables the ILO to sidestep some of the political controversies surrounding sex work through a more pragmatic, bottom-up strategy (see also NSWP, 2017).

In Ghana, the President at the time, John Drahami, welcomed the launch of Recommendation 200. In a statement that emphasised the link between HIV and decent work, he commented: "HIV and AIDS is a development issue and we each have a role to play towards accelerating our national response to ensure that PLHIV have access to care and support services as well as decent work and living conditions" (ILO, 2010b). Recommendation 200 is also cited as key factor informing the review of Ghana's National HIV/AIDS Workplace Policy conducted in 2012 (GAC, 2012a). The ILO has played an influential part in shaping national policy on HIV/AIDS and the workplace in Ghana since the early 2000s, namely by working in collaboration with the National Tripartite Committee-which comprises the Government, Organised Labour and Ghana Employers' Association-and the Ghana AIDS Commission. One notable example of this collaboration was the three-year ILO/USDOL "HIV/AIDS Workplace Education Project", which ran between 2003 and 2007, as part of a set of activities that shaped the adoption of Ghana's first National HIV/ AIDS Workplace Policy in 2005 (ILO, 2006). This policy drew extensively on the ILO Code of Practice on HIV/AIDS and the World of Work and, along with the revised 2012 policy, has provided a key framework for the roll-out of HIV prevention initiatives aimed at workers across the country (GAC, 2012a). Like Recommendation 200, Ghana's National HIV/AIDS Workplace Policy does not explicitly mention sex workers as a category of worker, although it is notable for emphasising a "human rights approach" premised on the "principle of gender equality" (GAC, 2012a: 11). It also acknowledges that women may be forced into "survival sex" due to HIV and that "the girl child is especially vulnerable to commercial sexual exploitation" (GAC, 2012a: 11).

The adoption and revision of the National HIV/AIDS Workplace Policy is contextualised by a broader set of shifts and evolutions in Ghana's strategic response to HIV over the past fifteen years, which, as Akua Gyamerah describes (2017), has moved from a 'general population' to a 'key populations' (KP) paradigm. Significantly, this has entailed recognition and prioritisation of the existence of a concentrated HIV epidemic among certain socio-demographic groups or KPs, including Female Sex Workers (FSWs) and Men who have Sex with Men (MSM). Data from 2019 estimates that HIV prevalence among sex workers in Ghana is $6.9 \%$ (UNAIDS, 2019) and the most recently available statistics indicate that there are around 52,000 women working in the commercial sex sector in the country (although this number is likely to be an under-estimation, given the challenges of quantification) (GAC, 
2012a; b). According to Gyamerah (2017), there are a range of factors and circumstances that have shaped the Ghanaian government's decision to prioritise KPs, such as MSM-what she terms Ghana's "paradigm shift" in HIV policy—which are simultaneously national, international and global in character. In particular, she identifies "growing epidemiological data, local and international NGO and CBO advocacy efforts and international HIV donor policy changes" (Gyamerah, 2017: 75) as providing the key impetus for change. In light of this, I do not wish to attribute a deterministic or overstated role to ILOAIDS in regard to Ghanaian HIV policy; rather my intention is to locate it as one significant actor and influence within a complex, multi-scalar and evolving development policy landscape. In the Ghanaian case, the imprint of the ILO's work is most notable in terms of policy orientation, content and detail (as in the HIV/AIDS National Workplace Policy). Additionally, in a framing that mirrors the ILO (2014) Leaving No One Behind publication, Ghana's HIV and AIDS Strategic Plan (2016) highlights the criminalisation of sex work (and indeed homosexuality) as a significant barrier hindering access to HIV prevention information and services. The 2016-2020 National HIV and AIDS Strategic Plan states specifically:

"In Ghana, stigmatisation and discrimination against KPs is widespread, both within state institutions and in the community at large simply because others disapprove of their behaviours. KPs are increasingly marginalised not only from society, but also from the services they need to protect themselves from acquiring and transmitting HIV. KPs therefore need their social and economic rights protected." (GAC, 2016: 94, italics mine)

The Strategic Plan thus identifies the protection of the "social", economic" and "human" rights of KPs as part of its core objectives, which are to be achieved through a range of activities, including support for community advocacy, stigma and discrimination reduction programs and identifying and establishing links with other "pro-poor economic and empowerment assistance" (GAC, 2016: 94) schemes. This commitment to protecting the economic and other rights of sex workers is ostensibly progressive and, depending on interpretation, could have far-reaching implications for the regulation and governance of the sex sector. However, the implementation of these policy objectives has been conditioned and constrained by the legal prohibition of sex work (and male same-sex relations) in Ghana, as well as widespread stigma and prejudice towards KPs, including among key national stakeholders. I explore these dynamics in detail below.

In terms of the law, Mgbako and Smith (2011: 1205) identify four "ideal-type" legal regimes governing sex work in Africa: prohibition; abolition; decriminalisation; legalisation. Ghanaian law can be broadly characterised as a prohibition regime, whereby the exchange of sexual services for payment is wholly criminalised, for sex workers, procurers and clients. Specifically, the Criminal Code, 1960 (Act 29) defines prostitution as "the offering by a person of his body commonly for acts of lewdness for payment although there is no act or offer of an act of ordinary sexual connection". Section 274 further prohibits the trade in prostitution, which is considered a misdemeanour and Section 276 of the code (amended by Section 14 of Act 554) provides that, "any person who persistently solicits or importunes in 
any public place or in sight of any public place for the purpose of prostitution shall be liable for a first offence to a fine and for a second or subsequent offences shall be guilty of a misdemeanour."

\section{From a rights-based public health framework to a labour rights approach? NGO interventions to support sex workers in Accra}

In Accra, a small number of NGOs and CBOs provide frontline human rights support to women working in the sex sector. At the time of my research (May-November 2020), grassroots outreach activities were primarily being carried out by one community-based organisation and two smaller-sized NGOs. Additional sexual health and human rights-focused interventions and funding has been provided though the HIV organisation, WAPCAS (Ghana-West Africa Program to Combat AIDS and STIs), and the Human Rights Advocacy Centre (HRAC), a medium-sized human rights NGO based in Accra, which has previously carried out research and advocacy work on sex workers' access to justice. These activities included training paralegals and setting a pro bono lawyers network to help marginalised groups such as sex workers (although this network was relatively limited in scale and geographic reach) (The Global Fund, 2019: 11). According to the organisations I spoke to, community-level outreach work aimed at sex workers in Accra has predominantly focused on HIV testing and counselling, capacity building, including vocational skills training, awareness-raising and other 'empowerment'-based activities, which are intended to help sex workers' claim their human rights, typically by reporting instances of violence or discrimination to the police and by accessing healthcare services. Activities vary in scale between the organisations; one $\mathrm{CBO}$, for example, works with small groups of sex workers over a period of several years; another NGO's programmes are aimed at several hundred sex workers across the Greater Accra area (and indeed in other parts of the country) at any one time. In terms of the demographics of the women, interviewees reported that almost all the sex workers that engage in their programmes are migrants, largely from the Northern, Central, Ashanti and Volta Regions of Ghana, as well as some women from neighbouring or nearby West African countries, such as Nigeria, Togo, Côte d'Ivoire and Liberia. Although they reported that a number of the women in their programmes had been trafficked - through deception-into sex work as children, this was described as the exception rather than the norm. Rather, a combination of poverty, lack of alternative livelihood opportunities, and a background of parental neglect and/or abuse were the most commonly cited reasons for entering sex work. ${ }^{8}$

In terms of funding, NGO- and CBO-based organisers highlight that while development funding for HIV prevention work among sex workers has been

\footnotetext{
${ }^{8}$ I include this detail on demographics and entry into sex work not to imply this is generally representative of sex workers in Accra; rather, it is intended to provide further context of the types of interventions, and to whom they are targeted,

being provided by civil society actors.
} 
available for some time, it is only over the past decade that space has opened up for more rights-based work, especially interventions that seek to address sex workers' living and working conditions. Greater NGO interest in decent work for sex workers (or, perhaps more accurately, in tackling indecent forms of work) is reflected, for example, in efforts to address women's safety and security at worksites such as brothels, including offering education programmes to brothel owners and advocacy work with sex workers experiencing violence or abuse. However, interviewees emphasised that their ability to expand into and address labour rights as civil society actors remains highly circumscribed, with much of the broader human rights advocacy carried out by grassroots organisations representing an "add-on" to existing HIV and sexual and reproductive health work. Indeed, all my interviewees emphasised that HIV prevention remains central to their work and funding streams, with the vast majority of interventions targeting sex workers being carried out under the auspices of the Global Fund to Fight HIV and Tuberculosis. In terms of self-organising, interviewees noted that there are currently no sex worker-led organisations operating in Ghana (although the community-based organisation, Women of Dignity Alliance, was singled out for its work in building a mutual support network for sex workers that focuses on livelihood issues as well as health concerns).

The limitations of a public health approach to sex workers' rights was raised frequently by all the NGO and community-based organisers I interviewed. As one Programme Officer noted:

"Interventions are coming in to protect them from HIV but not to fight to get a law that would protect them fully. Moving forward that should be a key area. Rather than doing a programme that is just HIV prevention." [Interviewee 1]

The limitations of sexual health approaches were typically linked to the tension between "empowering" sex workers to assert their rights and a socio-legal context of widespread stigmatisation and criminalisation. As one Outreach Officer explained:

"For one of the programmes, the intended outcome was for the women to be able to stand up for their rights, to advocate for their rights. But when we did the endline report, they still needed confidence to do that [...] It's because the law frowns on them. The Criminal Code is there, so coming out boldly to say, "this the work I do and you should respect me" and all that. They didn't feel confident to do that - to advocate for their rights as sex workers. [Interviewee 2]

To contextualise this tension, interviewees described wide-ranging human rights violations and abuses experienced by sex workers at the hands of (nonpaying) partners, clients and the police. This comprises physical and sexual violence, including battery and rape, extortion, harassment and arbitrary arrest. Periodic arrests - referred to as 'police swoops' - in which women are targeted for carrying condoms or lubricants, or for dressing 'in a particular way', for 
example-were again frequently linked to experiences of physical and/or sexual violence and extortion. Although swoops did not usually lead to prosecutions, one longstanding community organiser emphasised that they are used in a systematic way to harass sex workers, especially non-national migrant sex workers, since these women can be threatened with deportation for failing to show work visas or other forms of formal documentation. Indeed, a number of interviewees emphasised that sex workers who migrate to Ghana from other parts of West Africa are at even greater risk of violence and exploitation, since they are more likely to work as roamers or street-based sex workers, as opposed to tuutuu or "seaters"- typically older women that are home-based or work from other fixed locations, such as brothels_-and because they are viewed as "doubly illegal" in the eyes of the police. ${ }^{9}$

All my interviewees stated that the Criminal Code is a major barrier to the protection and promotion of sex workers' rights (and to the 'empowerment' and advocacy aims of the Government's Strategic Plan and other NGO-led human rights initiatives). As one Community Organiser explained:

"We don't have any labour rights specifically for female sex workers because sex work is illegal in Ghana. So it's all about rights in general. But we try as much as possible to work around it [the Criminal Code] for our female sex workers, so that they will not be violated." [Interviewee 4]

Interviewees further emphasised that existing policy mechanisms aimed at protecting and advancing sex workers' rights under the banner of public health afford, at best, extremely marginal protections, since sex workers continue to lack viable avenues for legal redress, fear reporting instances of violence to the police and encounter hostility and discrimination when they seek to access healthcare services. This parallels the dislocation described in the Indian context between the "rightsbased" approaches advocated by development actors focused on sexual health and the matrix of legal and political economic factors that work to systematically exclude, marginalise and oppress sex workers (Kotiswaran, 2011). However, in contrast to the dynamics highlighted by Kotiswaran-where "the public health complex has no legal agenda as such" (2011: 8) — my research indicates that some civil society organisations in Accra have become increasingly critical of health-first or health-only approaches, which is characterised by a growing emphasis on decriminalisation and recognising sex work as work. Frustration over the lack of progress made in empowering sex workers to claim their rights was cited by interviewees as a key factor underpinning this shift towards a politics of "sex work is work" among grassroots CBOs and NGOs:

\footnotetext{
9 Tuиtuи are estimated to comprise around $10 \%$ of commercial sex workers in Ghana, with roamers estimated to make up $90 \%$ (IOM, 2012). In addition to this typology, my research found that there are several other types of sex worker in Ghana, which includes male sex workers, and what my interviewees termed "high-class" sex workers, i.e. women who have completed secondary and potentially tertiary education, who typically provide escort and other entertainment services for expats, tourists and wealthy Ghanaians.
} 
"So that is something we said in the future we would really concentrate on because we didn't really see it - it was one of the outcomes-but we didn't really see it happening in the women for them to stand up for their rights." [Interviewee 2]

The Programmes Officer I interviewed explained further:

"It's one area I think in future we really need to look at: the law. I mean the construction of the legal enforcement institutions and the prohibition of legal aid." [Interviewee 1]

In addition to this shift among smaller community-based organisations and NGOs, the Human Rights Advocacy Centre is one of the most well-known national NGOs in Ghana to publicly call for the decriminalisation of sex work. In 2011, a study by HRAC uncovered widespread abuse of sex workers by the Ghana Police Service, which they found acted as both a key purveyor of violence and primary barrier to women accessing justice. Based on these findings, HRAC (2012) advised the Government of Ghana to: "Review the law applying to commercial sex work and repeal all provisions of the Criminal Offences Act that criminalize commercial sex work (s276)1; [...] Introduce laws to regulate the commercial sex work sector". This emphasis on decriminalisation illuminates not just the constraints but also the potential opportunities for advancing sex workers' rights within and beyond a public health framing, namely in terms of strengthening civil society capacity and commitment to sex workers' labour rights (and, in turn, to sex workers' self-organising, including the development of sex worker-led organisations) at the grassroots level. At the same time, however, several interviewees noted that their capacity to advocate for decriminalisation as smaller community-based organisations is constrained by the prevailing socio-legal environment, which makes it very difficult to speak out publicly on human rights abuses in the sex sector. In this way, the stigmatisation of sex work in Ghana not only hampers sex workers' ability to self-organise, but also the advocacy activities of civil society groups. For Interviewee 4, this underscores the broader importance of establishing and encouraging sex worker-led groups, as a means to amplify their voices and get their demands heard. She explained:

"We can't really change the law at the moment, so the best we can do is to empower the women to speak up for themselves. Because only they can bring the change they want in their communities." [Interviewee 4]

As these findings suggest, the decriminalisation aspect of NGO politics and practice has been introduced not in a top-down, policy-led way-for example through activities relating to the Decent Work Agenda-but rather through the work of the organisations themselves, who have responded to sex workers' needs and priorities (and had their own encounters with hostile institutional actors). As per Kempadoo's (1998) findings in the Dominican Republic, this suggests that this genre of sexual health intervention has-perhaps unintentionally-engendered change beyond its original aims, in this instance in terms of increasing civil society support for decriminalisation and beginning to connect groups and networks of sex workers on issues that matter to them. 
Indeed, in the context of entrenched stigma and discrimination and, as several interviewees noted, with little immediate prospect of legal reform in terms of decriminalisation, the linking of public health to human rights in development discourse was seen to have opened up important space for civil society organisations to come together and strategise on human rights issues in the sex sector. Thus, while interviewees emphasised the profound barriers to advancing sex workers' rights arising from criminalisation (and particularly the conduct of the Ghana Police Service), they also underscored the pragmatic value of developments in national policy and legal frameworks concerning HIV and sex work. According to one community organiser, the establishment of the Patient Charter in the Ghana Health Service and the passing of the Ghana AIDS Commission (GAC) Act in 2016 have been particularly helpful, in terms of enabling HIV-positive sex workers to claim their rights as a broader group of 'People Living With HIV' (PLHIV). As well as strengthening the rights of PLHIV in areas such as health, education and employment, the GAC Act contains provisions to penalise individuals who discriminate against PLHIV. Again, this was seen as useful mechanism to protect HIV-positive sex workers' rights. She notes:

"[the law] has been put in a simple way that clearly shows that if you are a sex worker and then you are HIV positive and then you are being abused by a health worker or any other person because of your status then you can report" [Interviewee 3]

At a governmental level, a number of interviewees also reported that things have slowly improved, with Ghanaian policymakers becoming increasingly receptive to discussions of sex work and cognisant of issues surrounding stigma and discrimination as these intersect with HIV. As one interviewee commented: "The understanding is coming bit by bit. So I believe that little by little we will get there." This sense of positive change was mediated, however, by the commonly-held view that the law on sex work was unlikely to change, which in turn rendered any significant progress in protecting the labour and other human rights of sex workers extremely difficult to envisage. Moreover, two organisers I spoke to described continuing hostility towards sex workers, the organisations that support them, and the idea of sex workers' rights from key national stakeholders and institutional actors, with some civil society organisations being accused of "promoting prostitution". As one Community Organiser noted:"[Sex work] is illegal in Ghana, so even when you meet policymakers and you talk about it-even though they are aware that these activities are going on in our country-when you talk about it, it more or less creates an argument. [They assume] that we CSOs who are working with them, we are trying to "promote the act' or their activity in the country." [Interviewee 5].

\section{Conclusion}

The Ghanaian case illustrates that while strides have no doubt been made in recognising sex workers as a key epidemiological category within development policy whose access to (a limited set of) health rights should be promoted and protected, 
grassroots civil society organisations have struggled to expand this rights-based approach to include a focus on labour. This reflects the tensions between the more bottom-up sexual health/decent work approach to sex work advocated by actors such as the ILO and Ghana's overarching legal prohibition regime, which creates an extremely hostile climate for sex workers (and the organisations that support them). The effectiveness of a sexual health/decent work approach to labour rights for sex workers is further constrained by the overwhelming focus of global development funding on HIV and by macro- and meso-level policy actors' failure to address the underlying political-economic factors that shape migrant women's entry into and experiences of labour exploitation within the sex sector in West Africa. These factors comprise, inter alia, poverty, lack of livelihood opportunities, unequal gender power relations and the organisation of social reproduction, as well as endemic patterns of gender-based violence, including from institutional actors such as the Ghana Police Service. In practice, then, even the relatively limited set of rights that are ringfenced for sex workers remain largely inaccessible. This lack of rights is particularly pronounced for women who migrate intra-regionally into sex work in the Ghanaian context. As such, the impact of expanding rights-based public health approaches to include labour rights is primarily discernible at the level of NGO/ CBO practice, with grassroots organisations moving towards a holistic understanding of rights based on the assumption that sex work is work and seeking to address and support a wider range of human rights issues beyond the field of health.

At a more macrolevel, the sexual health/decent work approach as articulated by ILOAIDS may make sense in the context of addressing HIV for workers whose status is recognised in law (and in light of competing and contested conceptualisations of decent work among different global policy actors and stakeholders). For sex work, however, not only do current policies fall far short of comprehensively including sex workers in the Decent Work Agenda (and in the gamut of legal protections this is intended to ensure), framing sex work primarily through the lens of HIV risks reinforcing stigma and discrimination, especially in contexts where sex work is criminalised. This has wide-ranging implications both within and beyond the Ghanaian context, given the lack of legal protections for sex workers and the relatively limited number of sex worker collectives across much of sub-Saharan Africa (Mgbako and Chi, 2011: 1181), as well as the continuing predominance of public health policy paradigms focused on HIV prevention. Fostering a more concrete decent work/public health policy nexus in practical terms-i.e. beyond the level of policy detail-may offer scope for more substantive change, particularly in terms of focusing on safety and security in the workplace and economic empowerment, for example, as in ILOAIDS' flagship work with sex workers in Thailand, which involved sex worker-led organisations on the ground (Empower, 2016). The issue of sex worker-led organisations is arguably the most salient here, given the multiple and interconnected relations of oppression and exploitation that shape migrant sex workers' experiences in Ghana-which cut across class, gender, ethnicity, nationality and citizenship - and the contradictions, omissions and ambiguities that continue to characterise global development policy efforts around sex work. In this way, the establishment of grassroots collectives that can organise and advocate on the political priorities that matter to sex workers is an especially pressing objective. 


\section{Declarations}

Conflict of interest Ellie Gore declare they have no conflict of interest.

\section{References}

Adepoju, A. (2005). Migration in West Africa: A paper prepared for the Policy Analysis and Research Programme of the Global Commission on International Migration. Lagos: Human Resources Development Centre. Retrieved from: https://www.iom.int/jahia/webdav/site/myjahiasite/shared/shared/ mainsite/policy_and_research/gcim/rs/RS8.pdf. Accessed 12 Jan 2021

Agustín, L. (2006). The disappearing of a migration category: Migrants who sell sex. Journal of Ethnic and Migration Studies, 32(1), 29-47. https://doi.org/10.1080/13691830500335325

Agustín, L. (2007). Sex at the margins: Migration, labour markets and the rescue industry. Zed Books.

Anarfi, J. K., Kwankye, S. O., \& Ababio, E. O. (2003). Migration from and to Ghana: A background paper. Development Research Centre on Migration, Globalisation and Poverty. University of Sussex.

Anderson, B., \& Andrijasevic, R. (2008). Sex, slaves and citizens: The politics of anti-trafficking. Soundings, 40, 135-145

Andrijasevic, R. (2010). Migration, agency and citizenship in sex trafficking. Palgrave Macmillan.

Awumbila, M., \& Ardayfio-Schandorf, E. (2008). Gendered poverty, migration and livelihood strategies of female porters in Accra, Ghana. Norsk Geografisk Tidsskrift, 62(3), 171-179. https://doi.org/10. 1080/00291950802335772

Awumbila, M., Deshingkar, P., Kandilige, L., Teye, J. K., \& Setrana, M. (2017). Brokerage in migrant domestic work in Ghana: complex social relations and mixed outcomes. London: DFID. Retrieved from: http://migratingoutofpoverty.dfid.gov.uk/files/file.php?name=wp47-awumbila-et-al-2017brokerage-in-migrant-domestic-work-in-ghana.pdf\&site $=354$

Bernstein, E. (2010) Militarized humanitarianism meets carceral feminism: The politics of sex, rights, and freedom in contemporary antitrafficking campaigns. Signs, 36(1), 45-71

Bernstein, E., \& Shih, E. (2014). The erotics of authenticity: Sex trafficking and "Reality Tourism" in Thailand. Social Politics, 21(3), 430-460. https://doi.org/10.1093/sp/jxu022

Bhattacharyya, G. (2005). Traffick: The illicit movement of people and things. Pluto Press.

Bindman, J., \& Doezema, J. (1997). Redefining prostitution as sex work on the international agenda. Anti-Slavery International. Retrieved from: https:/cdn.atria.nl/epublications/1997/Redefining_Prost itution.pdf. Accessed 12 Jan 2021

Blanchette, T. G., Silva, A. P., \& Bento, A. R. (2013). The Myth of Maria and the imagining of sexual trafficking in Brazil. Dialect Anthropology, 37, 195-227. https://doi.org/10.1007/s10624-013-9296-Z

Criminal Code. (1960). (Act 29). Ghana

Cruz, K. (2018). Beyond liberalism: Marxist feminism, migrant sex work, and labour unfreedom. Feminist Legal Studies, 26(1), 65-92. https://doi.org/10.1007/s10691-018-9370-7

Di Ruggiero, E., Cohen, J. E., Cole, D. C., \& Forman, L. (2015). Competing conceptualizations of decent work at the intersection of health, social and economic discourses. Social Science and Medicine, 133, 120-127. https://doi.org/10.1016/j.socscimed.2015.03.026

Doezema, J. (2001). Ouch! Western feminists' wounded attachment to the "third world prostitute." Feminist Review, 67(1), 16-38

Doezema, J. (2005). Now you see her, now you don't: Sex workers at the UN trafficking protocol negotiation. Social and Legal Studies, 14(61), 61-89

Ehrenreich, B., \& Hochschild, A. R. (2003). Global woman: Nannies, maids, and sex workers in the new economy. Holt Paperbacks.

Elias, J., \& Holliday, J. (2019). Who gets 'Left behind'? Promises and pitfalls in making the global development agenda work for sex workers-Reflections from Southeast Asia. Journal of Ethnic and Migration Studies, 45(14), 2566-2582. https://doi.org/10.1080/1369183X.2018.1456747

Empower. (2016). Moving toward decent sex work sex worker community research decent work and exploitation in Thailand. Chiang Mai, Thailand. Empower Foundation. Retrieved from: http://unact.org/wp-content/uploads/2017/01/Moving_Toward_Decent_Work_EMPOWER.pdf. Accessed 12 Jan 2021 
Enloe, C. (1990). Bananas, beaches, and bases: Making feminist sense of international politics. University of California Press.

Federici, S. (2006). Prostitution and globalization: Notes on a feminist debate. In M. Davies \& M. Ryner (Eds.), Poverty and the production of world politics. (pp. 113-136). Palgrave Macmillan.

Fudge, J., \& McCann, D. (2015). Unacceptable forms of work: A global and comparative study. ILO.

García, M. R. (2018). The ILO and the oldest non-profession. In U. Bosma \& K. Hofmeester (Eds.), The lifework of a labor historian: Essays in honor of Marcel van der Linden. (pp. 90-114). Brill.

Ghana AIDS Commission. (2012a). National workplace HIV and AIDS policy. GAC.

Ghana AIDS Commission. (2016). National HIV \& AIDS strategic plan 2016-2020. GAC.

Ghana AIDS Commission. (2012b). Integrated bio-behavioural survey, preliminary findings. GAC.

Global Network of Sex Work Projects. (2017). Policy brief: Sex work as work. Global network of sex work projects. Edinburgh: NSWP. Retrieved from: https://www.nswp.org/sites/nswp.org/files/policy_brief_sex_work_as_work_nswp_-_2017.pdf. Accessed 12 Jan 2021

Gyamerah, A. (2017). Unburying the ostrich's head and opening pandora's box: A paradigm shift to address HIV among men who have sex with men in Ghana. Unpublished doctoral dissertation. Columbia University

Hashim, I., \& Thorsen, D. (2011). Child migration in Africa. Zed Books.

Heumann, S., Siegmann, K.A., \& Empower Foundation (2016). Towards new perspectives on work precarity and decent work for sex workers. In K. Biekard, W. Harcourt \& P. Knoringa (Eds.), Exploring Civic Innovation for Social and Economic Transformation (pp. 168-191). London: Routledge

Human Rights Advocacy Centre (2012) United Nations universal periodic review-Ghana-submission to the UN Human Rights Council. Accra: HRAC. Retrieved from: https://lib.ohchr.org/HRBodies/ UPR/Documents/Session14/GH/JS3_UPR_GHA_S14_2012_JointSubmission\%203_E.pdf

International Labour Organization (ILO). (2016). ILO standards on forced labour-The new protocol and recommendation at a glance. International Labour Office, Fundamental Principles and Rights at Work Branch (FUNDAMENTALS). ILO

ILO. (1998). ILO declaration on fundamental principles and rights at work and its follow-up. Geneva: ILO. Retrieved from: https://www.ilo.org/declaration/thedeclaration/textdeclaration/lang--en/index. htm. Accessed 12 Jan 2021

ILO. (2001). Combating trafficking in children for labour exploitation in West and Central Africa: Synthesis report. Geneva: ILO. Retrieved from: https://www.ilo.org/ipec/Informationresources/WCMS_ IPEC_PUB_776/lang--en/index.htm. Accessed 12 Jan 2021

ILO. (2006). ILO evaluation summary: HIV/AIDS workplace education. Geneva: ILO. Retrieved from: https://www.ilo.org/wcmsp5/groups/public/---ed_mas/---eval/documents/publication/wcms_ 083707.pdf. Accessed 12 Jan 2021

ILO. (2010a). Recommendation concerning HIV and AIDS and the World of Work, 2010 (No. 200). Geneva: ILO. Retrieved from: https://www.ilo.org/global/topics/hiv-aids/WCMS_142706/lang--en/ index.htm. Accessed 12 Jan 2021

ILO. (2010b) Implement the ILO recommendation on HIV and AIDS (No. 200). Geneva: ILO. Retrieved from: https://www.ilo.org/wcmsp5/groups/public/---ed_protect/---protrav/---ilo_aids/documents/ image/wcms_215373.pdf. Accessed 12 Jan 2021

ILO. (2011). Convention No. 189 Decent work for domestic workers. Geneva: ILO. Retrieved from: https://www.ilo.org/wcmsp5/groups/public/---ed_protect/---protrav/---travail/documents/publication/wcms_161104.pdf. Accessed 11 Jan 2021

ILO. (2012). Getting to zero through the world of work: Reaching out to sex workers and their clients. Geneva: ILO. Retrieved from: https://www.ilo.org/wcmsp5/groups/public/@ed_protect/@protrav/@ ilo_aids/documents/genericdocument/wcms_185717.pdf. Accessed 12 Jan 2021

ILO. (2014). Leaving no one behind: Reaching key populations through workplace action on HIV and AIDS. Geneva: ILO. Retrieved from: http://www.ilo.org/aids/Publications/WCMS_249782/lang--en/ index.htm. Accessed 12 Jan 2021

International Organization for Migration (IOM). (2020). Internal and cross-border adult sex trafficking in Ghana: A baseline report. Accra: IOM. Retrieved from: https://publications.iom.int/system/files/ pdf/tip-study-ghana.pdf. Accessed 12 Jan 2021

IOM. (2012). HIV vulnerability among female sex workers along Ghana's tema-paga transport corridor. Accra: IOM. Retrieved from: https://www.iom.int/files/live/sites/iom/files/pbn/docs/HIV-Vulnerabil ity-among-FSWs-along-Tema_Paga-Transport-Corridor.pdf. Accessed 12 Jan 2021

Jeffreys, S. (2009). The industrial vagina: The political economy of the global sex trade. Routledge. 
Kallock, S. (2018). Sex work. In J. Elias \& A. Roberts (Eds.), Handbook on the international political economy of gender. (pp. 392-411). Edward Elgar Publishing

Kempadoo, K. (1998). The migrant tightrope: experiences from the Caribbean. In K. Kempadoo \& J. Doezema (Eds.) Global Sex Workers Rights: Rights, Resistance and Redefinition (pp.124-139). London: Routledge

Kempadoo, K. (2015). The modern-day white (wo)man's burden: Trends in anti-trafficking and anti-slavery campaigns. Journal of Human Trafficking, 1(1), 8-20. https://doi.org/10.1080/23322705.2015. 1006120

Kempadoo, K. (1999). Slavery or work? Reconceptualizing third world prostitution. Positions, 7(1), $225-237$

Kempadoo, K. (2004). Sexing the Caribbean: Gender, race, and sexual labor. Psychology Press

Kempadoo, K., \& Ghuma, R. (1999). For the children: Trends in international policies and law on sex tourism. In K. Kempadoo (Ed.), Sun, sex and gold: Tourism sex work in the Caribbean. (pp. 291308). Maryland: Rowman and Littlefield

Kempadoo, K., Sanghera, J., \& Pattanaik, B. (eds.) (2016). Trafficking and Prostitution Reconsidered: New Perspectives on Migration, Sex Work, and Human Rights. London: Routledge

Kinney, E. (2014). Raids, rescues, and resistance: Women's rights and Thailand's response to human trafficking. In C. R. Showden \& S. Majic (Eds.), Negotiating sex work: Unintended consequences of policy and activism. (pp. 145-170). University of Minnesota Press

Kotiswaran, P. (2011). dangerous sex, invisible labor: Sex work and the law in India. Princeton Press

Kotiswaran, P. (2014). Beyond sexual humanitarianism: A post-colonial approach to anti-trafficking law. UC Irvine Law Review, 4, 353-406. https://doi.org/10.2139/ssrn.2939251

Laar, A., \& DeBruin, D. (2017). Key populations and human rights in the context of HIV services rendition in Ghana. BMC International Health and Human Rights, 17, 20

Lim, L. (Ed.). (1998). The sex sector: The economic and social bases of prostitution in Southeast Asia. International Labour Office

Litchfield, J. \& Waddington, H. (2003). Migration and poverty in Ghana: Evidence from Ghana living standards survey. Sussex Migration Working Paper No. 10. Sussex Centre for Migration Research. University of Sussex

Makofane, K., Gueboguo, C., Lyons, D., \& Sandfort, T. (2013). Men who have sex with men inadequately addressed in African AIDS National Strategic Plans. Global Public Health: an International Journal for Research, Policy and Practice, 8(2), 129-143

Manzo, K. (2005). Exploiting West Africa's children: Trafficking, slavery and uneven development. Area, 37(4), 393-401. https://doi.org/10.1111/j.1475-4762.2005.00644.x

Mgbako, C. A., \& Smith, L. A. (2011). Sex work and human rights in Africa. Fordham International Law Journal, 33(4), 1178-1220

Mgbako, C. A. (2016). To live freely in this world: Sex worker activism in Africa. NYU Press.

Magar, V. (2012). Rescue and rehabilitation: A critical analysis of sex workers' anti-trafficking response in India. Signs, 37(3), 621-623

O'Connell Davidson, J. (2006). Will the real sex slave please stand up? Feminist Review, 83, 4-22

O'Connell Davidson, J. (2013). Troubling freedom: Migration, debt, and modern slavery. Migration Studies, 1(2), 176-195. https://doi.org/10.1093/migration/mns002

O'Connell Davidson, J. (2015). Modern slavery: The margins of freedom. Palgrave Macmillan.

Okyere, S. (2017). "Shock and Awe": A critique of the Ghana-centric child trafficking discourse. AntiTrafficking Review, 9, 92-105

Onyango, M. A., Adu-Sarkodie, Y., Agyarko-Poku, T., Asafo, M. K., Sylvester, J., Wondergem, P., Green, K., Wambugu, S., Brennan, A., \& Beard, J. (2015). "It's all about making a life": Poverty, HIV, violence, and other vulnerabilities faced by young female sex workers in Kumasi, Ghana. Journal of Acquired Immune Deficiency Syndromes, 68, S131-S137. https://doi.org/10.1097/QAI.0000000000 000455

Padilla, M. (2007). Caribbean pleasure industry: Tourism, sexuality, and AIDS in the Dominican Republic. University of Chicago Press.

Penttinen, E. (2008). Globalisation, prostitution and sex trafficking: Corporeal politics. Routledge.

Peterson, V. S. (2003). A critical rewriting of global political economy. Routledge.

Pettman, J. J. (1997). Body politics: International sex tourism. Third World Quarterly, 18(1), 93-108

Piper, N., \& Uhlin, A. (2002). Transnational advocacy networks, female labor migration and trafficking in east and Southeast Asia: A gendered analysis of opportunities and obstacles. Asian and Pacific Migration Journal, 11, 171-195 
Rai, S. M., Brown, B. D., \& Ruwanpura, K. N. (2019). SDG 8: Decent work and economic growth-A gendered analysis. World Development, 113, 368-380. https://doi.org/10.1016/j.worlddev.2018.09. 006

Showden, C. R., \& Majic, S. (eds.), (2014). Introduction: The politics of sex work. In Negotiating sex work: Unintended consequences of policy and activism (pp. xiii-xl). University of Minnesota Press

Smith, N. J. (2012). Body issues: The political economy of male sex work. Sexualities, 15(5-6), 586-603

Standing, G. (2008). The ILO: An agency for globalization? Development and Change, 39(3), 355-384. https://doi.org/10.1111/j.1467-7660.2008.00484.x

Strauss, K. (2012). Coerced, forced and unfree labour: Geographies of exploitation in contemporary labour markets. Geography Compass, 6(3), 137-148. https://doi.org/10.1111/j.1749-8198.2011. 00474.x

Tandia, O. (1998). Prostitution in Senegal. In K. Kempadoo \& J. Doezema (Eds.), Global sex workers: Rights, resistance, and redefinition. (pp. 240-245). Routledge.

The Global Fund. (2019). Baseline assessment-Ghana scaling up programs to remove human rightsrelated barriers to HIV services. Geneva: The Global Fund. Retrieved from: https://www.theglobalf und.org/media/8720/crg_humanrightsbaselineassessmentghana_report_en.pdf. Accessed 11 Jan 2021

UNAIDS, (2019). HIV prevalence by country: Ghana. UNAIDS [online]. Retrieved from: https://www. unaids.org/en/regionscountries/countries/ghana. Accessed 12 Jan 2021

Vosko, L. F. (2002). 'Decent Work': The shifting role of the ILO and the struggle for global social justice. Global Social Policy, 2(1), 19-46. https://doi.org/10.1177/1468018102002001093 